\title{
A Nutritional Comparison Study of Three Oaks Species Grown in Gara Mountains
}

\author{
Khalid Ismail Saleem (D) ${ }^{1}$, Khaleda Haji Abdullah ${ }^{2}$, Karvan Faraj Saadallah ${ }^{3}$, Hilbin \\ Ibrahim Abdullah ${ }^{4}$,Rand Omar Khalo ${ }^{5}$ \\ 1, 2, 3, 4, 5 Department of Forestry, Collage of Agricultural Engineering Sciences, \\ University of Duhok. \\ ${ }^{1}$ Corresponding Author: khalid.ismail@uod.ac
}

\begin{abstract}
Article history:
Received 16 June 2021

Accepted 27 July 2021

keyword : Oaks leaves, Autumn season, Nutritional value, Feed substitute.
\end{abstract}

\begin{abstract}
The preferred livelihood assets for meat and nutritious milk in thousands villages of Kurdistan region/Iraq are sheep and goats. They generally rely on free roaming in rangeland during the growing seasons. In order to maintain their livestock during the scarcity of forages at winter seasons, the leaves and twigs of (Quercus aegilops, Q. infectoria and Q. libani) are harvested and dried as (dry leaf faggots) at autumn season to use as major substitute of feed. This study was conducted to evaluate the nutritional values of those three oaks species' leaves at the same time of collecting period. Gara Mountains were chosen due to the wide presence of all three species. Leaves samples were collected at late September 2015 at elevation about 1250 MASL. The results have shown differences in chemical composition. Q. libani recorded higher content of dry matter (DM), ash and crude protein (CP), and lower content of crud fibre $(\mathrm{CF})$. Higher content of ether extract (EE) was recorded in both Q. aegilops and Q. libani. The higher content of nitrogen free extract (NFE) and potassium (K) were recorded in $\mathrm{Q}$. infectoria. While Q. aegilops recorded higher (CF) content. All Quercus species can be used as alternative feed substitute for small ruminant especially with some additives (such as salt, vitamin, and water), but more nutritive value was $\mathrm{Q}$. libani then $\mathrm{Q}$. infectoria followed by $\mathrm{Q}$. aegilops. Therefore, the priority should be for Q. libani in foremost followed by $\mathrm{Q}$. infectoria when dry leaves faggot were made.
\end{abstract}

\section{Introduction}

Approximately $75 \%$ of Kurdistan Region/Iraq are forests and covered by oaks species and mainly dominated by (Quercus aegilops, Q. infectoria and Q. libani), especially in high elevations (1200 MASL and higher), beside many other species such as Prunus microcarpa, Pistacia mutica, Pistacia khinjuk, Pyrus syriaca, Acer monspessulanum, Crataegos azarolus, and Anagyris foetida ( Besefky, 2011).

Oaks leaves are an important source of forage for small ruminant during periods of year at which quality and quantity of pastures forage are limited, especially during late summer, autumn and winter seasons.
The harvested and dried of oaks leaves and twigs (dry leaf faggots) of (Quercus aegilops, Q. infectoria and Q. libani), in addition to other roughages, are being the main sources of forage that farmers to rely on to feed their livestock during the forage scarcity seasons.

There are many researches were conducted in Kurdistan (Al-Alousy, 1997; Besifky, 1999; Besefky, 2011) in attempt to evaluate the nutritive value of one or two of oaks species, but all were conducted during spring season while the environmental factors are adequate for growing forages (such as forbs, grasses, shrubs and trees) widely grown in Kurdistan/Iraq rangelands.

There is no information about nutritive value of oaks leaves (Quercus aegilops, Q. infectoria and Q. libani) in this region at autumn season, and it how far meet nutritional requirements of livestock, since local farmer and animal breeders 
of Kurdistan region have always practiced collecting oak leaves (as dry leaf faggots) at autumn season (figure 2 and 3 ).

Thousands of local people of Kurdistan villages in mountains are mostly farmers, they depending on farming and livestock (mainly sheep and goats) for their livelihood and welfare. They basically rely on rangelands for feeding their livestock, collecting and reserving oaks leaves (in a form of dry leaf faggots) during autumn can be very useful for that purpose during winter season when pasture forages have been depleted (figure 4).

As it known that chemical composition is changing during the growth stage and seasonal changes as it mentioned by Singh and Todaria, (2012) that influenced composition of Quercus semecarpifoila. While Brian and Philip, (1991) reported that lignin and DM content of Quercus gambelii were increased with maturity stages, while CP content was decreased.

Minz, et.al . (2013) concluded that feeding Quercus semecarpifolia leaves enhanced feed efficiency, nutrient utilization and growth performance of goats' kids as compared with grass hay.

Digestibility and content of CP in bur oak leaves (Quercus macrocorpo) on the oak trees are higher than those on the ground (fallen leaves). The content of $\mathrm{CP}$ was declined with advancing season in bur oak leaves. (Forwood and Owensby, 1985).

Kamalak, et.al. (2014) mentioned to the potential reduction of methane when leaves from
Quercus coccifera were fed to small ruminant in order to decrease emission of methane.

Due to scarcity of feed in hilly regions of India, The animals usually remain undernourished for a long period of the year, therefor, leaves of Quercus leucotrichophora are potential feed resource for ruminants (Paswan and Sahoo, 2012).

There is little information available about the nutritive value of oak leaves at spring season, but there is no information available about the nutritive value of the three oaks species' leaves during the collection and storage period during early and mid-autumn in Iraqi Kurdistan region.

This study aimed to determine the nutritive value of oaks leaves (Quercus aegilops, Q. infectoria and Q. libani) that dominated in Gara Mountains at autumn (simultaneously with collecting and making dry leaf faggots by local farmer and animal breeders) to investigate the ability of those three species in providing valuable animal feed and how far it can meet local livestock nutritional needs during forages paucity season.

\section{Materials and Methods}

\section{Study area}

The study was carried out on Gara Mountains (figure 1) at late September 2015. The study area was allocated in Gara mountains between Latitudes $36^{\circ} 57^{-} .00 \mathrm{~N}$ and $37^{\circ} 02^{-} .00 \mathrm{~N}$, and Longitudes $43^{\circ} 14^{-} .00 \mathrm{~N}$ and $43^{\circ} 22^{-} .00 \mathrm{~N}$ E. at elevation about 1250 MASL.

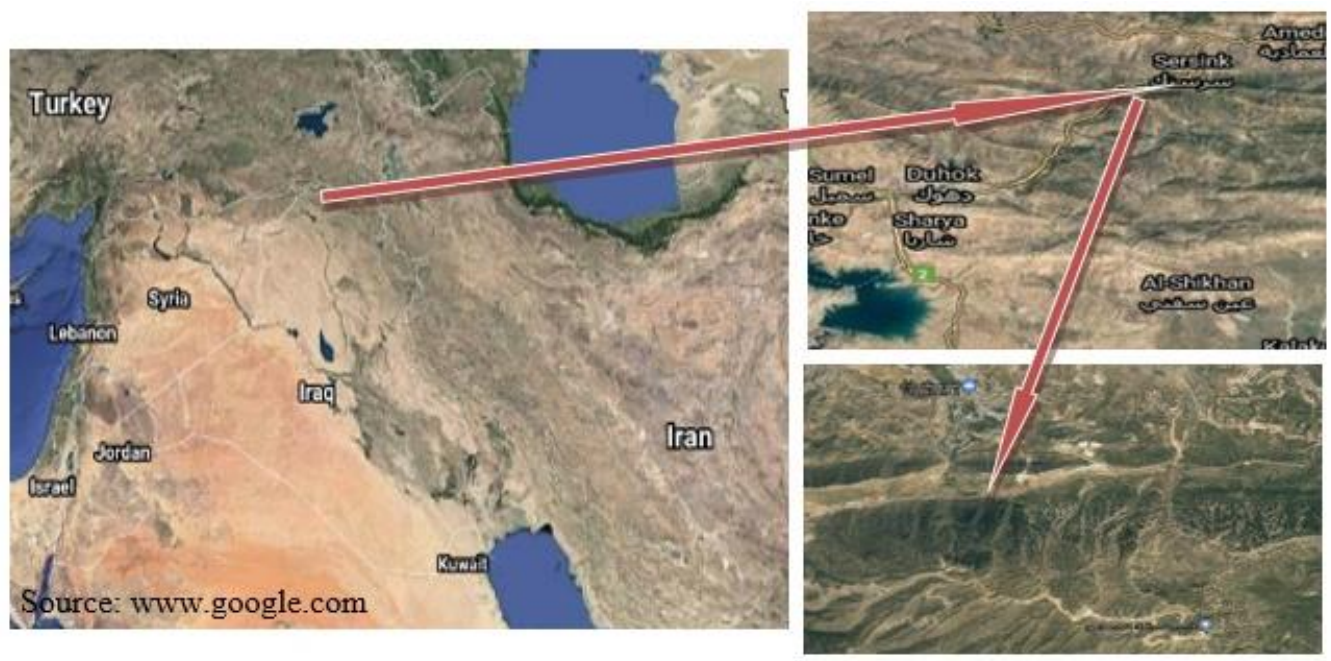

Figure 1. The study area at Gara Mountains, Duhok governorate, Kurdistan region/Iraq 


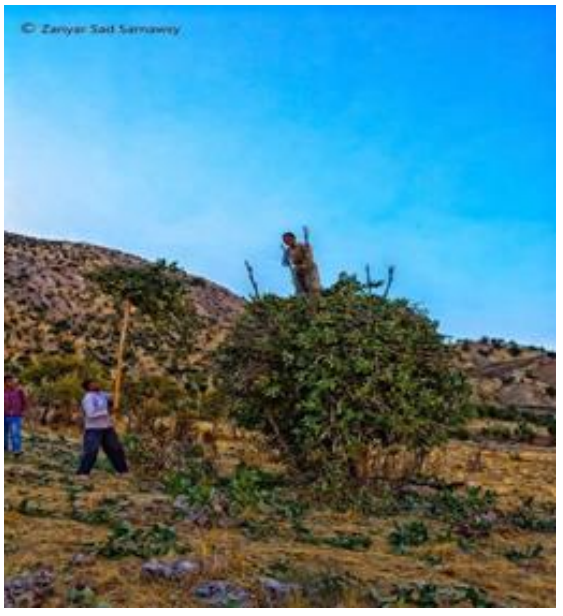

Figure 2. Process of making above ground dry leaf faggots

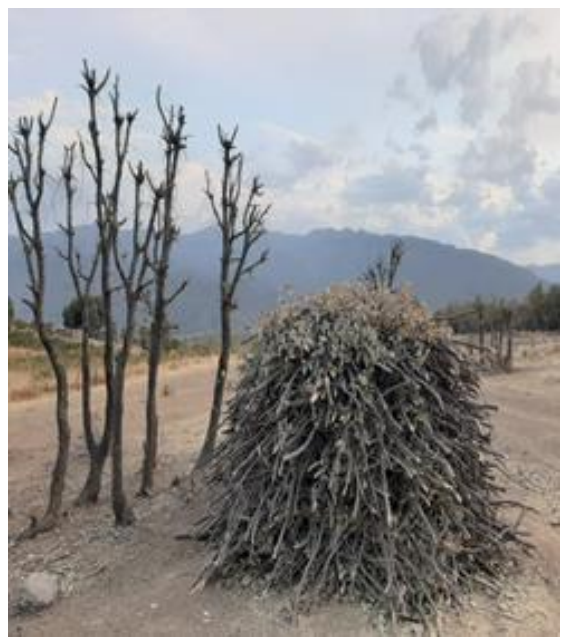

Figure 3. On-ground dry leaf faggots

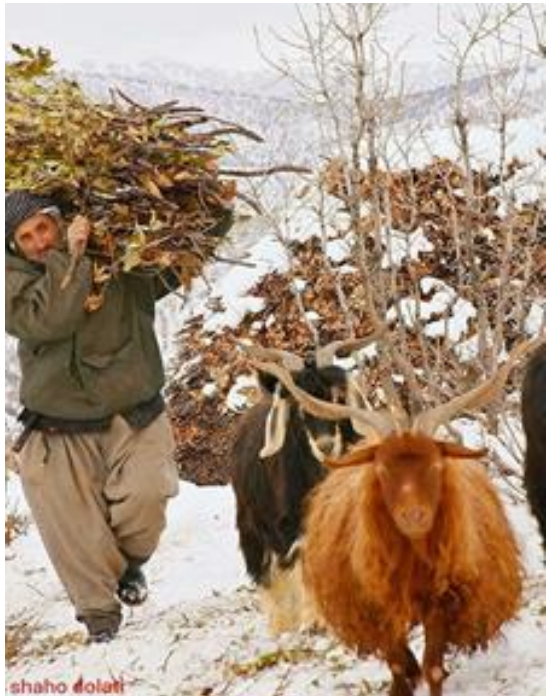

Figure. 4. Using dry leaf faggots during winter season

\section{Field work}

\section{A- Locations}

Four sub-locations (replications) of the same geographical aspect (north aspect) were selected; since oaks species including Quercus infectoria, Quercus aegilops, and Quercus libani were growing in all sub-locations.

\section{B- Sampling}

In every sub-location, over a $500 \mathrm{~g}$ of healthy leaves from over ten individual trees of each species were collected in polyethylene bag separately and numbered.

\section{Laboratory work}

All samples were weighted, air dried for 48 hours and dried in the oven at $70^{\circ} \mathrm{C}$ until constant weight (Phillip et al., 1978). Weighing of wet and oven dried samples were preformed using a digital balance GE812 Sartorius (0.01 g sensitivity).

\section{Chemical analysis}

Plants samples were prepared according to Jackson (1958) after grinding samples by electric blender for determination of Nitrogen and Potassium content. The chemical analysis included the following components:

1- Dry matter content was determined by drying sample in oven at $70^{\circ} \mathrm{C}$ until constant weight (g) (Phillip, 1978).

2- Crude protein content was determined using Micro kjeldahl for determination of $(\mathrm{N})$ according to AOAC (2002), then CP was estimated by the following equation:

Crude protein $\%=$ Nitrogen $\%$ x 6.25 (protein factor) according to (Le-Dividich et al, 1976).

3- Ether extract content was determined using Soxhlet apparatus and extraction with diethyl ether according to (AOAC, 2002).

4- Crude fibres content was determined according to AOAC (2002) after extracting crude fat from the samples.

5- Nitrogen free extract content was determined according to (Aleem, 1978).

6- Minerals (Ash) content was determined using muffle furnace and burning the samples at $550^{\circ} \mathrm{C}$ for five hours according to (AOAC, 2002).

7- Potassium content was determined using flame photometer according to (AOAC, 2002).

The mean values of chemical compositions of the leaves for Quercus infectoria, Quercus aegilops, and Quercus libani were shown in table (1). 
Table 1. Chemical compositions of three oaks species

\begin{tabular}{|c|c|c|c|c|c|c|c|}
\hline \multirow{2}{*}{ Ingredients } & \multirow{2}{*}{ DM \% } & \multicolumn{5}{|c|}{ \% in DM } & \multirow{2}{*}{ K } \\
\cline { 3 - 7 } Species & & Ash & EE & CP & CF & NFE & \\
\hline Quercus infectoria & 51.85 & 8.15 & 5.75 & 5.62 & 13.72 & 66.75 & 22.75 \\
\hline Quercus aegilops & 62.05 & 7.90 & 8.4 & 6.85 & 13.95 & 62.85 & 15.42 \\
\hline Quercus libani & $\mathbf{6 5 . 0 0}$ & $\mathbf{9 . 0 5}$ & $\mathbf{8 . 3 5}$ & $\mathbf{7 . 6 2}$ & $\mathbf{1 1 . 0 5}$ & $\mathbf{6 3 . 9 2}$ & $\mathbf{2 1 . 7 5}$ \\
\hline
\end{tabular}

\section{Statistical Analysis}

Randomized complete block design (RCBD) was applied to estimate the effect of species on chemical composition of three oaks species, the collected data of this study were analyzed using Statistical Analyzes System (SAS) (version 6.2), as shown in table (2).

Table 2. Anova table for chemical composition of three oaks species

\begin{tabular}{|c|c|c|c|c|c|c|c|c|}
\hline \multirow{2}{*}{ S. O. V } & \multirow{2}{*}{ d. f. } & \multicolumn{7}{|c|}{ MSE } \\
\cline { 3 - 9 } & & DM & Ash & EE & CP & CF & SC & K \\
\hline Oaks Species & 2 & $190.44^{*}$ & 1.46 & $9.73^{*}$ & $4.07^{*}$ & $10.41^{*}$ & $16.23^{*}$ & $63.1^{*}$ \\
\hline Sub-locations & 3 & 1.65 & 0.45 & 0.22 & 0.82 & $0.56^{*}$ & 2.43 & 2.39 \\
\hline
\end{tabular}

$*$ refers to signification at $\mathrm{p}<0.05$.

\section{Results and Discussion}

The three oaks species included in current study showed significant differences in chemical composition according to (Duncan, 1955) at $\mathrm{p}<$ 0.05 of significant level.

\section{Dry matter content}

The higher content of DM (figure 5) was recorded in $Q$. libani, even though it was not significantly differed with $Q$. aegilops; but both of them were significantly differed with $Q$. infectoria.
The DM content is not clearly differs among different species, but it also differ due to the geographical location. The $Q$. libani highest content of DM due to adequate environmental conditions for growing this species

\section{Ash Content}

It is obvious (figure 6) that the higher content of minerals was associated with Q. libani, but there were no significant differences among three oaks species were shown. These results were higher

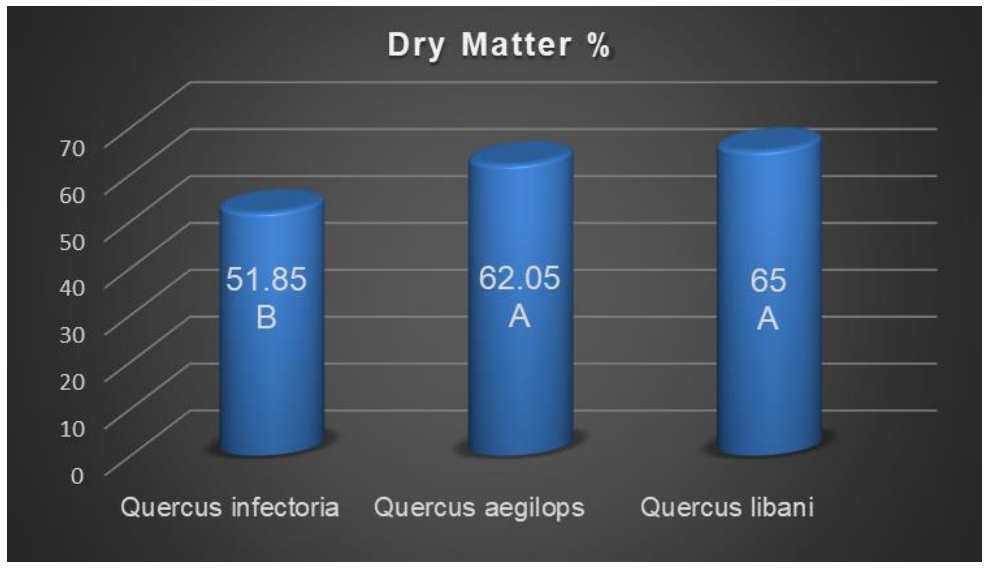

Figure.5. Dry matter percent of three oaks species

than what obtained by Besefky (2011) for Q.

aegilops and Q. infectoria at spring season. 


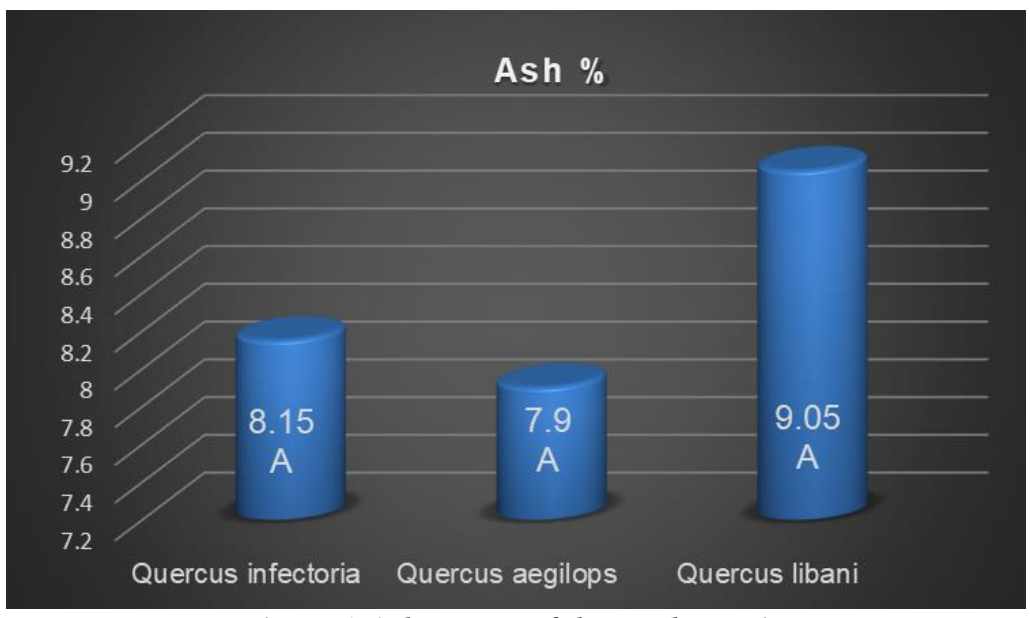

Figure.6. Ash content of three oaks species

\section{Ether Extract Content}

Figure 7 shows no significant differences between Q. libani and Q. aegilops in EE content, but both of them significantly exceeded Q. infectoria. Although the habitat is more adequate for growing Q. libani and Q. infectoria but Q. aegilops recorded higher content of EE; and this fluctuation of $\mathrm{EE}$ content mostly due to genetic factor. These results are comparable to results obtained by (Besefky, 2011).

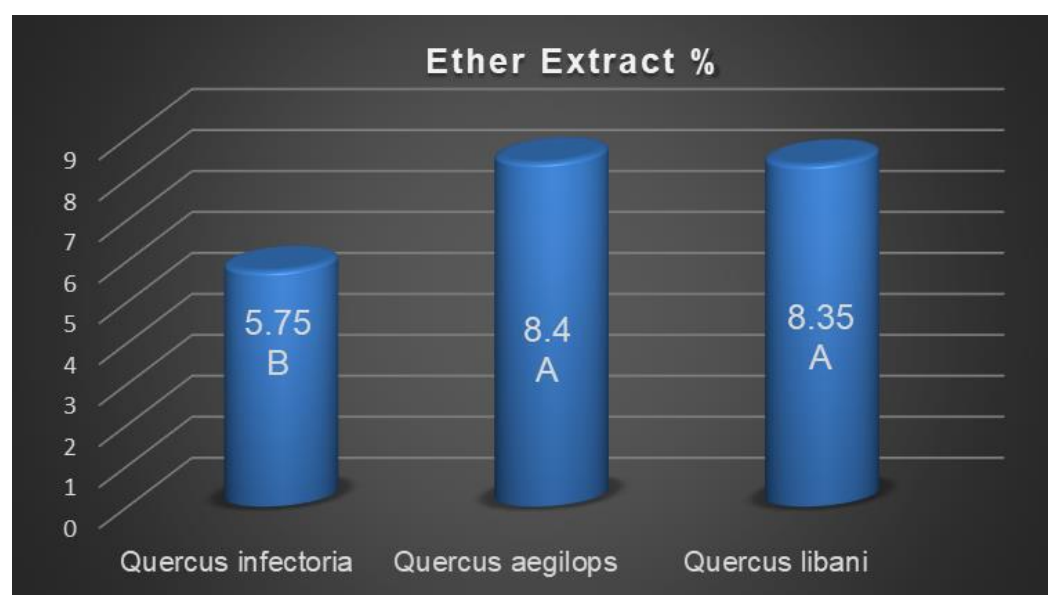

Figure 7. Ether extract content of three oaks species

\section{Crude Protein Content}

Quercus libani recorded the higher content of CP $7.62 \%$ and it was significantly deferred with $\mathrm{Q}$. infectoria but none was differed significantly with Q. aegilops as showed in figure 8. These results are more probably due to adequate altitude (more than 1200 MASL) and surrounding environmental conditions for growing Q. libani. Crude Protein content was almost three times higher in Q. aegilops and $\mathrm{Q}$. infectoria than that obtained by Besefky (2011) at spring season. 


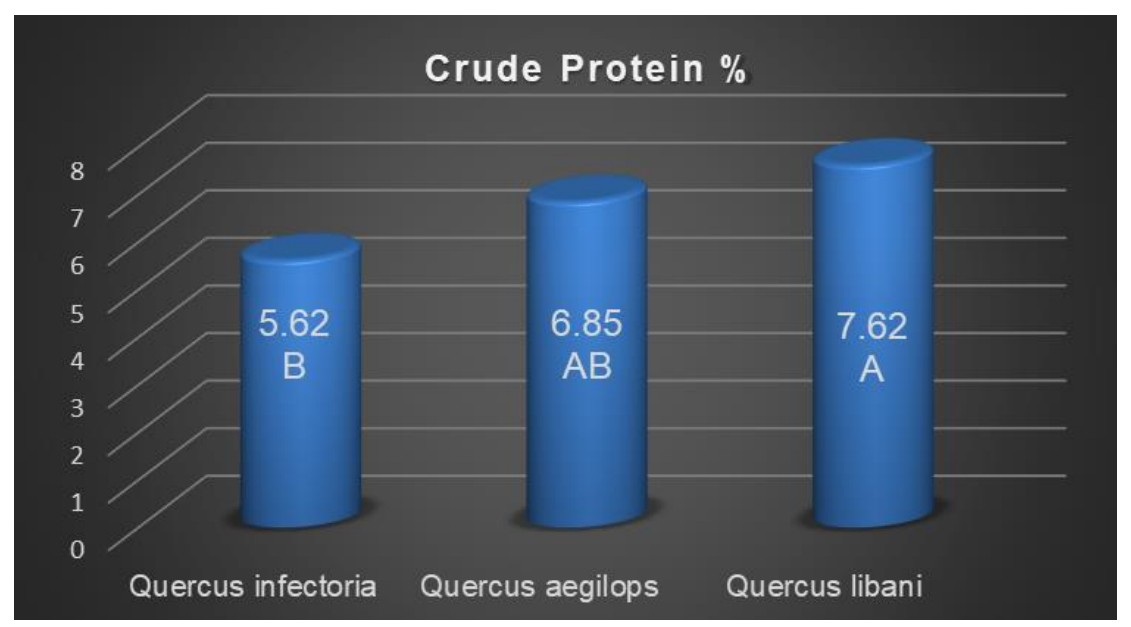

Figure 8. Crude protein content of three oaks species

\section{Crude fibre Content}

Unlike crude protein, Q. libani recorded the lower CF content of $11.05 \%$. Q. aegilops recorded higher content of $13.95 \%$ followed by Q. infectoria $(13.17 \%)$ but both significantly exceeded with Q. libani (figure 9).
These results may prove that surrounding environment is more adequate for growing of $\mathbf{Q}$. libani. Crude fibre content was declined to the half at autumn season as compared to reported by Besefky (2011) at spring season.

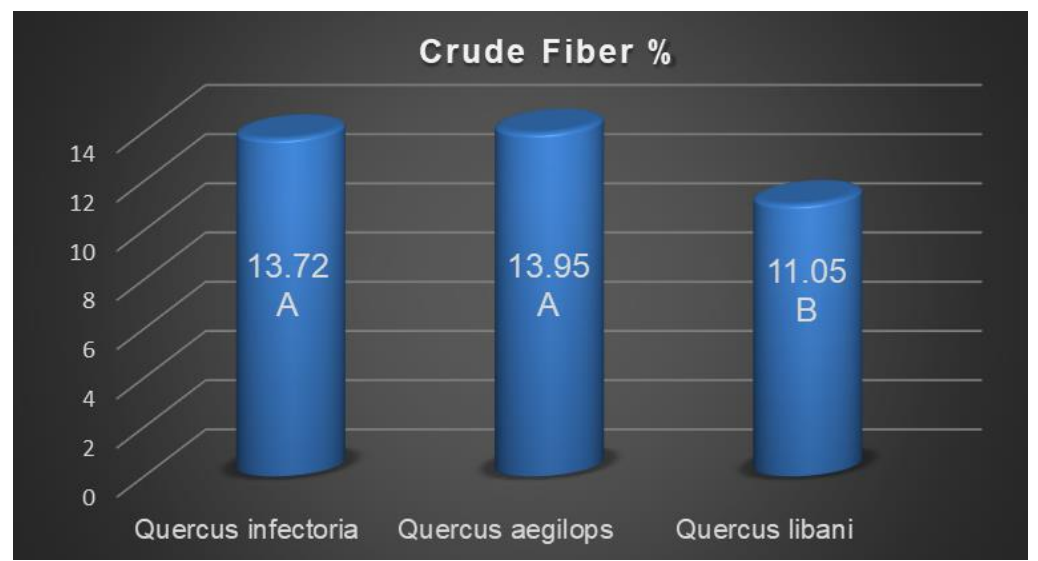

Figure 9. Crude fibre content of three oaks species

\section{Nitrogen Free Extract}

Quercus infectoria recorded the higher content of NFE (figure 10) and it was significantly differed with both Q. libani and Q. aegilops, with no significant differences between the last two species. Generally, NFE content is higher than that obtained at spring season (Besefky, 2011). 


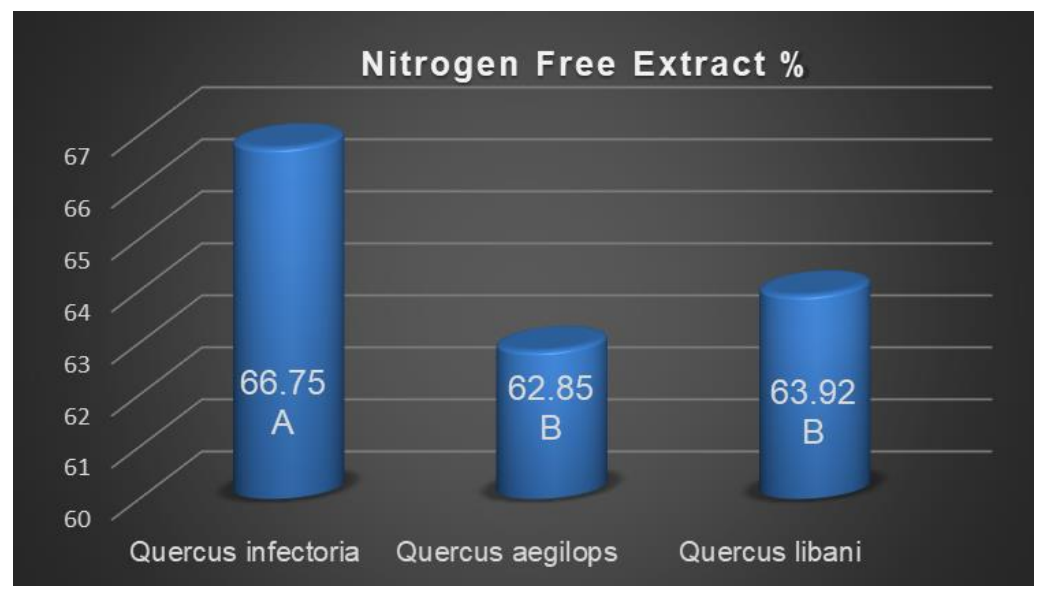

Figure 10. Nitrogen free extract content of three oaks species

\section{Potassium Content}

There were no significant differences between Quercus infectoria and Q, libani in K content (figure 11), but they both significantly exceeded Q. aegilops.

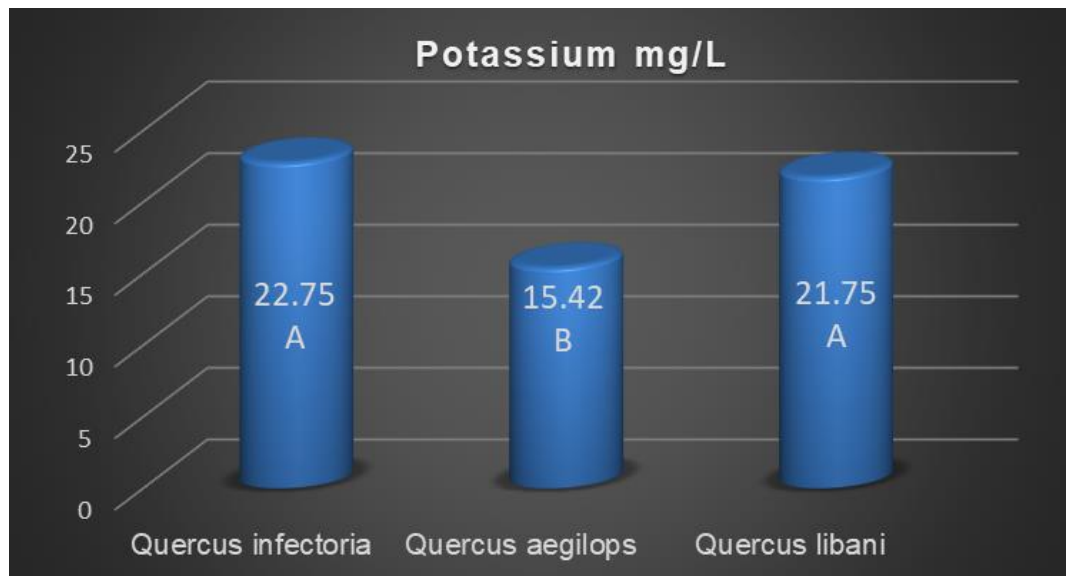

Figure 11. Potassium content of three oaks species

\section{Conclusions}

This study can leads to conclude that evaluating and determining the forages qualities are very important for local farmers and livestock breeders in order to at least maintain their alive animals and healthy during forage paucity at very low energy cost, especially those forages that widely available in region such as Quercus aegilops, Q. infectoria and Q. libani. It can also conclude that oaks leaves collected at autumn season were more nutritive than those collected at spring season (for Q. infectoria and Q. aegilops) as compared with results obtained by (Besefky, 2011). Farther more, the three oaks species can be used to substitute expensive feed during the paucity of pasture forages. And finally, the more nutritive species is Q. libani, Q. infectoria followed by Q. aegilops depending to their nutritive value and palatability.

According to observations and questions asked local livestock breeders and farmers, sheep and goat preferred Quercus libani, followed by Q. infectoria and then $\mathrm{Q}$. aegilops is the less favorable. According to the results obtained, the following recommendation might be considered:

Firstly, collecting oaks leaves should be done at autumn season exclusively. Secondly, giving priority to Q. libani and then Q. infectoria when dry leaves faggot were made due to their nutrient value and palatability. Thirdly, planning for increasing Q. libani on count of Q. aegilops in the region. And finely, further studies are required to 
determine the digestibility of the studied oaks species

\section{Conflict of Interests}

We have no conflicts of interest to disclose.

\section{Acknowledgments}

Special thanks go to the Department of forestry at the College of Agricultural Engineering Sciences, University of Duhok for providing the laboratory to conduct this research. And also appreciations go to the staff of the central laboratory of the collage.

\section{References}

Al-Alousy, Y. M. Q. 1997. Seasonal variations in nutritive value of shrubby and pastoral plants in Sinjar, Maqloob, and Ninevah, Namrood forests. Ph. D. Thesis. College of Agri. and Forestry/ Univ. of Mosul.

Aleem, A. 1978. Markhor population dynamic and food availability in Chitral Gol. Game Sancturay. Pakistan J. of Forestry 28 (3): 159165.

AOAC. 2002. International. Official methods of analysis of AOAC International. 17th edition. 1st revision. Gaithersburg, MD, USA, Association of Analytical Communities.

Besifky, K. I. S. 1999. A contrastive confining and evaluation of plant covering under natural forestry conditions in Dosky Quarter/ Duhok. M. Sc. Thesis, College of Agriculture/ Univ. of Duhok.

Besefky, K. I. S. 2011. Effect of Elevations and Aspects on Natural Vegetation Characteristics of Some Locations in Duhok Governorate/ Iraqi Kurdistan Region. Ph. D. Dissertation, College of Agriculture/ Univ. of Duhok.

Brian L. Dick and Philip J. Urness. 1991. Nutritional value of fresh Gambel oak browse for Spanish goats. Journal of Range Management 44(4).

Forwood, J. R. and C. E. Owensby. 1985. Nutritive Value of Tree Leaves in the Kansas Flint Hills. Journal of Range Management 38(1).
Jackson, M. L. 1958. Soil chemical analysis. Englewood cliffs. Prentice, Hall Inc. New Jersey. U. K.

Kamalak, Adem, Kaefee Gibbar Hassan, Shimaa Mahmood Ameen, Hawar Maher Zebari, Ayad Hadi Hasan and Fatih Aslan. 2014. Determination of Chemical Composition, Potential Nutritive Value and Methane Emission of Oak Tree (Quercus coccifera) Leaves and Nuts. Kahramanmaras Sutcu Imam University,Turkey.

Le-Dividich, J., F. G. Gahop and M. Chensot. 1976. Using waste bananas as world animal feed review.

Minz, P. S. D., B. A Sahoo, K. Garg, M. Shankar and A. K. Sharma. 2013. Effect of feeding oak leaves on nutrient utilization and growth performance of goats in Kumaon hills of temperate sub Himalayas. Indian Veterinary Research Institute, Mukteshwar, Uttarakhand 263138 India.

Paswan, V. K. and A. Sahoo. 2012. Feeding of oak (Quercus leucotrichophora) leaves and evaluation for its potential inclusion in the feeding of native heifers of Kumaon Himalaya. Tropical Animal Health and Production (DOI10.1007/s11250-012-0159-4).

Phillip, S. J., S. Singh, and W. K. Lauenron. 1978. The structure and function of ten western American grasslands. J. Eco. 166: 251-285.

SAS Institute Inc. 2014. SAS® Visual Analytics 6.2 for SAS ${ }^{\circledR}$ Cloud: Quick-Start Guide. Cary, NC: SAS Institute Inc.

Singh B. and N. P. Todaria. 2012. Nutrients composition changes in leaves of Quercus semecarpifolia at different seasons and altitudes. Annals of Forest Reaserch. 